\title{
Can Learning Be Fun and Games? The Influence of Everyday Language on Students' Content Vocabulary Use and Concept Understanding
}

\author{
GERALDINE MONGILLO \\ William Paterson University
}

"Wow! I aced that quiz and it was all because of those games!"

(Sam, grade 7)

From the first moment I entered Ms. Woods' (all names pseudonyms) $7^{\text {th }}$ grade science class I sensed a level of energy and excitement not encountered in the other classrooms visited. I wondered what made this class different and on subsequent visits I discovered one possibility Ms. Woods frequently integrated instructional games throughout all of the curricular units. The games were interactive and often the students created both questions and answers utilizing game show formats (e.g., Jeopardy®, \$25,000 Pyramid®, Memory). My experience as an early childhood teacher has taught me the educational value of play and games but this was the first time I observed its use as an instructional activity in a middle school classroom. This observation piqued my curiosity and prompted this inquiry into whether or not the participation in instructional games helped older students learn the language and concepts of science. This inquiry was part of a broader study, which included an examination of the influence of play on attitudinal development that is discussed at length elsewhere (Mongillo, 2008). The guiding research questions discussed here are: a) does participation in instructional games influence scientific language use, and b) does participation in instructional games influence scientific concept understanding?

\section{Literacy Learning in Science Education}

Current trends in science education (the subject area examined in this study) call for students to be literate in scientific matters with the expectation that they will be able to knowledgably engage in conversations pertaining to science and public issues (Hurd, 1998; Miller, Pardo, \& Niwa, 1997; National Science Board, 2002). As educators, we know that the comprehension of scientific language is necessary to become literate in the domain and that it is vital that students exhibit proficiency in reading, writing, and speaking in the language specific to the subject area (Alvermann, 2004; Lemke, 1990; Moje et al., 2004). However, for some students comprehension of scientific content knowledge is difficult because the terminology and concepts are unfamiliar. Traditional instructional techniques such as lecture or skill drill do not work for many of our students, particularly for those who are already struggling with literacy skills. The language of science can intimidate and alienate students, making them feel illiterate in the genre. Within the context of game play, students have the opportunity to construct meaning through the use of their everyday language and knowledge acquired outside of school (i.e., home, community, peers, media, etc.). Moje et al (2004) referred to these additional sources as funds of knowledge (Moll \& Greenberg, 1990), and suggest that neither teachers nor the students themselves acknowledge these funds of knowledge or their accompanying discourse styles. This linear type of thinking inhibits both the students and 
teachers from making connections between their everyday and academic funds of knowledge.

During games, a social situation, students are more relaxed and apt to use their everyday (out-of-school) language associated with play activities. Although these games are played in school, the context does not demand the strict use of academic (in-school) language. Games present an opportunity for adolescents to utilize their diverse literacies in a way that acknowledge their diverse ways of knowing and ways of speaking.

Game play, often considered 'meaningless' in school environs, was explored by Gee (2003) and one significant finding suggested that the language of everyday domains must be acknowledged and applied to future learning. Starting with and building on everyday language and knowledge can be a method to bridge the gap between students' out-of-school and in-school funds of knowledge. The language and concepts of science are situated in a specific, academic language that "is not really lucid or meaningful if one has no embodied experiences within which to situate its meanings in specific ways" (Gee, 2003, p. 106). In contrast to traditional classroom practice, game play provides a relaxed setting where students can play with words, express personal knowledge, and venture guesses in a non-threatening situation.

\section{What is an Instructional Game?}

Ms. Woods specifically chose games that required small group interactions, fostering dialogue and collaborative problem solving. Instructional games for the purpose of this study were defined as having two or more players, an element of challenge and competition following a predetermined set of rules, and criteria for winning (Jacob \& Dempsey, 1993; King, 1986). Games are recognized as instructional when they facilitate learning and improve skills or knowledge (Lepper \& Chabay, 1985; Malone \& Lepper, 1987).

The games used in this study were well known to the students either through television shows or leisure time activities. Ms. Woods built up a store of games overtime from previous classes and often sought student suggestions and input. Some of the games such as Jeopardy were created by other classes and reused over and over again. For Jeopardy, the questions were listed by category and the responses are given in the form of a question (i.e., Question: The science that deals with the history of the earth and life as recorded in rocks; Response: What is Geology?). Gameshow simply followed a question and answer format where the goal was for contestants to earn points for answering posed questions correctly. They played the games in groups of five or six and played either as individuals, or in teams, depending on the game. The students often created the questions and answers based on the course content. The specific focus of the games observed in this study were based on the unit vocabulary words (Appendix A) and assigned text readings. Pyramid was a newly implemented game that was based on a television game show that required the participants to describe a concept or term by providing a list of synonyms or related words. Memory is a popular game played from ages 3 to adult that requires the player to turn over two matching cards from a group of cards placed face down on a table. Each turn, the player can only flip over two cards and this is why the game is called Memory. The students were responsible for negotiating the rules, timekeeping, and keeping score. The teacher acted as judge in matters that needed clarification. The games did not use or require technology except when they used the Internet to research answers. This was intentional on Ms. Woods' part because she felt that these interactive games afforded collaboration, discussion, and social interaction. To avoid undue competition Ms. Woods did not offer prizes to the winners explaining that the opportunity to learn through games was a reward in and of itself.

In this study, Ms. Woods reported that the underlying strategy for using games as an 
instructional tool was to provide a new or novel approach to a traditional learning activity that employed gaming skills already familiar to her students. Her short-term goal was to provide opportunities for her students to build and share their understandings about science content through an informal, collaborative activity. Ms. Woods' long-term goal was to enable her students to talk like scientists or in her own words, "To get them [her students] to use the vocabulary appropriately instead of saying thing-a-ma-jig or what-cha-ma-call-it."

\section{Rationale and Review of the Literature}

This study drew on three areas of research to support and strengthen the understanding of scientific language use and concept understanding. Theories related to language and literacy (Gee, 1996, 1999a, 1999b, 2003; Street, 1995), the social nature of learning (Hodson, 1998; Lemke, 1990; Solomon, 1993), and scientific literacy (Bybee, 1995; Hurd, 1998; Yager, 2000) are discussed. These theories maintain that literacy and learning are above all social in nature, broadening the construct of what it means to be literate in today's society.

Gee (1999a) described the means by which we communicate within situated contexts as the Discourse that serves to signify and distinguish the various communities we participate in at specific times. Discourse is inclusive and characterized by, "ways of acting-thinking-feelingemoting-valuing-gesturing-posturing-dressing-thinking-believing-knowing-speaking-listening (and in some Discourses, reading-and-writing as well)" (Gee, 1999a, p. 38). Gee emphasized that we are participants in several Discourse communities, each different, and recognizable by members as appropriate ways of acting and communicating (social language). For example, the social language accepted and employed during game play may be more like the everyday language we use in conversations with friends than the language and protocol used in a typical school setting. When participating in a game we do not wait to be called upon by the teacher or await teacher approval for correct answers.

Often scholars and educators view the language and protocols used in games as less than adequate for school learning. According to Street (1995), the various literacies commonly used outside of schools are marginalized by mainstream society. Street referred to this as the "pedagogization" of literacy and concluded after studying both home and school literacies that educators have adopted the use of "objectified language" where school-based literacy practices are treated as though it is an entity to master, separate and apart from the language employed outside of school. This may be one reason we see little use of games in K-12 schooling.

A personalized approach to teaching and learning science as suggested by Hodson (1998) embraces the use of common, everyday speech associated with the various social languages each of us employs at different times. The authoritative language of science often bores students and the strict use of academic terms creates a barrier that keeps students from seeing any purpose or connection between formal science and their everyday lives. To avoid this disconnect Hodson suggests that educators, "pay much closer attention to the transitions from everyday understanding to scientific ways of understanding and from everyday ways of communicating to scientific ways of talking and arguing" (p. 5). This constructivist approach allows students the time and space to talk through their ideas and Hodson suggests that teachers make provisions for this type of exploration. Game play would be one such situation where students collaboratively express ideas and are exposed to differing viewpoints under the guidance of the teacher.

Solomon (1993) posited that children learn common sense scientific knowledge through socially constructed explanations of 'lived experiences.' These experiences include talk and play, which provide the opportunity for "reconstructing what they thought" (p. 89) using socially 
constructed language. Children (as well as adults) will use social language to talk through problems or ideas in order to comprehend them. However, the examples cited of classroom discourse demonstrated that students' attempts to transition from informal social language to the more formal scientific knowledge show a divide between the two ways of knowing. It appears that consensus in group discussions often prevails and new theories are slowly assimilated through careful expert guidance.

Similarly, a study of adolescents' in- and out-of-school literacy practices suggested that students do not make connections between multiple literacies (Moje et al, 2004). Students are often discouraged from using their knowledge gained in everyday world experiences, and are implicitly asked "to reframe what and how they know in terms of problems to be solved" (p. 46). In another study (Kamen et al, 1997) examining the role of language in science education, discourse analysis suggested that there is not only a need to allow students multiple ways to express their thoughts and ideas, there is a need to explore student-to-student conversations. This perspective of what is means to be scientifically literate reshapes the way teachers look at their content and instructional methods to include students' everyday knowledge (Hurd, 1998; Kamen et al, 1997; Lemke, 1990). It also calls for teachers to rethink their methods of instruction to include more student discussion and idea sharing.

In this study, I also considered Lemke's (1990) social semiotic theory that proposed teaching and learning science is tied to the construction of meaning through the use of language to communicate concepts and ideas that are bound by social processes. Learning "to talk" science as Lemke described involves making connections between the academic terms and scientific content, or what Lemke called thematic patterns. These patterns are found in the classroom discourse where a scientific topic is discussed and meaning is constructed through talk. In order for students to use the technical terms in appropriate ways they need opportunities to show how words and meanings (thematic patterns) relate to each other. This is accomplished through classroom discourse strategies (e.g., instructional games) that build relationships through talking science in the everyday language, instead of the exclusive use of the dull, alienating language associated with science.

Finally, the present study was also informed by the perspective that defines scientific literacy as "a continuum of understanding about the natural and designed world" (Bybee, 1997, p. 86). Bybee (1997) proposed a framework that describes four categories of scientific knowledge, which link the mechanical aspects of literacy (reading, writing, speaking as a member of the scientific community) as well as the broader, more philosophical principles of scientific literacy (science for all students). The framework proposes degrees of scientific literacy categorized as nominal, functional, conceptual and procedural, and multidimensional. According to Bybee (1997) nominal scientific literacy is described as the level where the individual associates names with a general area of science; functional scientific literacy is where an individual responds appropriately and adequately to vocabulary associated with science as well as read and write passages with simple scientific vocabulary; conceptual and procedural scientific literacy occurs when the individual demonstrates an understanding of both the parts and the whole of science as disciplines; and multidimensional scientific literacy consists of understanding the essential conceptual structures of science as well as the features that make that understanding more complete. All students do not necessarily reach the same level of understanding on the continuum for each topic, however, this framework serves as a guide for "curriculum development, assessment, research, professional development, and teaching science to a broad range of students" (Bybee, 1997, p. 86). It is significant to note that at present, school 
curriculums and current science standards aim for the functional level of scientific literacy.

Science education reforms (e.g., National Research Council, 1996) call for an expanded definition of scientific literacy that reflects a philosophy based on inquiry that encompasses real world learning and content relevant to the decisions made in everyday life (Hurd, 1998; Yager, 2000). Further, the curriculum needs to reflect the rapid changes in society and technology spurred by the information age and focus on human welfare (Hurd, 1998). In order to achieve these outcomes, students must apply literacy skills that enable them to make sense of scientific content by translating academic language and concepts into meaningful, everyday contexts. Lemke's (1990) study demonstrated that the didactic teaching models driven by textbook learning that prevail in middle school education do not address these issues.

\section{Methodology}

Game play is not often used as an instructional strategy for older learners, however, in the natural setting of Ms. Woods' class, game play was frequently incorporated. This field study sought to understand the influence of game play on science learning through the systematic study of this phenomenon. The overarching goal was "to build up an explanation of it" (Henn, Weinstein, \& Foard, 2006, p. 49) and to interpret the data to gain new insights (Peshkin, 1993) concerning the value of games.

The middle school where this study took place was located in a suburban county in the northeastern United States. This school served approximately 1200 students, grades 6, 7, and 8, drawing from two surrounding communities, one an upper middle class community of diverse ethnicities and the second a lower income community of diverse ethnicities.

\section{Participants}

Ms. Woods, the science teacher, is a European-American female who has an undergraduate degree in education. Ms. Woods has been teaching science for ten years at the middle school level and has been trained in a specialized science program. She is considered a master teacher, training other science teachers in the methods and philosophy of the program.

The student participants in this study were recruited and selected from one average ability section of Ms. Woods' seventh-grade class and the average age was 12-years-old. There were a total of 23 students in the class and when they were invited to participate, 21 of 23 agreed. Six participants ( 2 female, and 4 male) were randomly selected from the pool of volunteers. Three of the participants were of European American descent, one was East Indian, one was Middle Eastern, and one was of Asian descent. English was the first language of all the participants. Three of the participants had an A average in the course and three had a B average. All of the participants were eager to play games and interested in the study.

\section{Data Sources}

Data were collected and triangulated (Bogdan \& Biklen,1992) from teacher and student interviews, audio-taped game sessions, student documents (e.g., student created game questions, self-evaluation forms, pre- and post-assessments, and the final quiz) and researcher field notes. Data collection commenced at the start of the 6-week Earth History unit where the researcher was present at least 3 days each week. During the data collection period, five games were implemented and observed: Memory, Gameshow, \$25,000 Pyramid (twice), and Jeopardy. According to Ms. Woods, each science unit covers specific vocabulary and concepts. She selected 26 vocabulary words she deemed critical to understanding the unit topic (mountain 
building-see Appendix A). Observations on non-game days afforded the researcher the opportunity to record the specific scientific vocabulary and concept use by both the teacher and students in traditional classroom lessons and activities.

\section{Data Analysis}

The data were analyzed using holistic procedures including discourse and text analysis, and the constant comparative method (Corbin \& Strauss, 1990). To determine the significance of the data obtained, data from multiple sources were coded using Bybee's (1997) framework for scientific literacy as a lens in order to discover patterns in the participants' vocabulary and concept use. Based on the initial findings, the framework was modified to reflect the level of scientific understanding demonstrated by the participants and categorized as: Unacquainted, Nominal, Functional, and Conceptual. In addition, the category described by Bybee as conceptual and procedural literacy was modified to only conceptual literacy in this study because the data collected did not include observations or evidence that reflected procedural knowledge or skills. Unacquainted was used where it was obvious that the participant was never exposed to the term or concept and the multidimensional was not used because the participants were novices and this level was too advanced for them to achieve.

In addition to using Bybee's framework to code and compare the data, further text analysis was done to ascertain concept understanding by utilizing Lemke's definition of concept as "thematic items and their customary semantic relationships" (1990, p. 91). In order to achieve reliability, two university colleagues sampled the data applying the aforementioned coding system for describing the levels scientific literacy for vocabulary use. Overall, $90 \%$ agreement was reached.

\section{Results}

Both Bybee (1995) and Lemke (1990) suggested that the minimal acceptable level of scientific literacy should enable students to use the language of science at the functional level. Based on this standard, the functional level was defined in this study as the ability to: respond appropriately and adequately to vocabulary associated with science as well as read and write passages with simple scientific vocabulary (Bybee, 1997).

\section{Vocabulary Use in Games}

The first research question asked to what extent the use of instructional games influenced the students' use of scientific vocabulary. Specifically, Bybee's (1997) framework for scientific literacy was applied to discover the student's level of scientific vocabulary use demonstrated in their responses during game play, pre- and post-assessments, and the final quiz. Table 1 provides abbreviated definitions of the categories used in this study along with sample questions and participant responses as they were coded in each category. 
Table 1 Examples and Definitions of the Levels of Scientific Literacy for Assigned Vocabulary

\begin{tabular}{|l|l|l|l|l|}
\hline & \multicolumn{4}{|c|}{ Level of Scientific Literacy } \\
\hline Sample Questions & Unacquainted & Nominal & Functional & Conceptual \\
\hline & $\begin{array}{l}\text { No Answer } \\
\text { Off Topic }\end{array}$ & $\begin{array}{l}\text { Partial } \\
\text { Answer, } \\
\text { Educated } \\
\text { Guess }\end{array}$ & $\begin{array}{l}\text { Adequate } \\
\text { and } \\
\text { Acceptable }\end{array}$ & $\begin{array}{l}\text { Connects } \\
\text { Term to } \\
\text { Concept }\end{array}$ \\
\hline $\begin{array}{l}\text { Game: Pyramid 2 } \\
\text { A fissile rock that is formed } \\
\text { by the consolidation of clay, } \\
\text { mud, or silt__ }\end{array}$ & I don't know. & $\begin{array}{l}\text { Limestone. } \\
\text { Sandstone. }\end{array}$ & Shale. & None \\
\hline $\begin{array}{l}\text { Game: Jeopardy } \\
\text { Name one purpose of the } \\
\text { Powell expedition. }\end{array}$ & No response. & $\begin{array}{l}\text { What is } \\
\text { gold? }\end{array}$ & $\begin{array}{l}\text { What is to } \\
\text { create a } \\
\text { map? }\end{array}$ & $\begin{array}{l}\text { What is to } \\
\text { study } \\
\text { Geology? }\end{array}$ \\
\hline $\begin{array}{l}\text { Game: Gameshow } \\
\text { Q: Rusty metal is an example } \\
\text { of }\end{array}$ & Rock. & $\begin{array}{l}\text { Physical } \\
\text { weathering. }\end{array}$ & $\begin{array}{l}\text { Chemical } \\
\text { weathering. }\end{array}$ & Oxidation. \\
\hline
\end{tabular}

First, the levels of scientific literacy achieved for the assigned vocabulary words across all games were analyzed. These results are provided in Table 2 and are listed in the order the games were introduced during the unit of study.

Table 2 Levels of Scientific Literacy for Assigned Vocabulary Demonstrated In Games

\begin{tabular}{|l|c|c|c|c|c|}
\hline Game & $\mathrm{N}$ & $\begin{array}{c}\text { Unacquainted } \\
\text { No Response, } \\
\text { Off topic, or } \\
\text { Inaccurate } \\
N(\%)\end{array}$ & $\begin{array}{c}\text { Pominal } \\
\text { Educated } \\
\text { Guess } \\
N(\%)\end{array}$ & $\begin{array}{c}\text { Functional } \\
\text { Appropriate } \\
\text { Response } \\
N(\%)\end{array}$ & $\begin{array}{c}\text { Conceptual } \\
\text { Vocabulary } \\
\text { To Larger Concept } \\
N(\%)\end{array}$ \\
\hline Memory & 24 & $2(8)$ & $1(4)$ & $21(88)$ & $0(0)$ \\
\hline Gameshow & 87 & $1(1)$ & $37(43)$ & $47(54)$ & $2(2)$ \\
\hline Pyramid & 38 & $1(3)$ & $17(45)$ & $18(47)$ & $2(5)$ \\
\hline Pyramid 2 & 38 & $0(0)$ & $14(37)$ & $24(63)$ & $0(0)$ \\
\hline Jeopardy & 19 & $0(0)$ & $6(32)$ & $12(63)$ & $1(5)$ \\
\hline Totals & 206 & $4(2)$ & $75(36)$ & $122(59)$ & $5(3)$ \\
\hline
\end{tabular}

Approximately one game was played each week starting in the third week of the unit. Findings for levels of scientific literacy across all game responses $(N=206)$ showed that $59 \%$ of the usage of the assigned vocabulary during game play achieved the functional level of scientific literacy, with $36 \%$ of the responses at the nominal level. This result demonstrated that the participants as a group predominantly used the assigned vocabulary in appropriate and adequate ways to answer the game questions. Less often they displayed nominal or token uses of the terms. In only $2 \%$ of 
the occurrences were the responses coded as unacquainted that demonstrated that the participants recognized the assigned vocabulary words at the nominal level or above. Participants achieved the conceptual level of scientific literacy at a slightly higher rate (3\%) overall than the unacquainted level, but significantly less than the nominal or functional categories. It should be noted, however, that across the data sources (pre- and post-assessment, final quiz), only in games did the participants achieve the conceptual level of scientific literacy for vocabulary.

The game Memory was the first game played during the unit and was implemented in the third week of the unit. All of the 26 assigned vocabulary words were previously introduced to the students through homework assignments, classroom review and readings. The teacher created one card for each of the 26 vocabulary words and one card each composed of the definition. The object of the game is to match the vocabulary word with the appropriate definition.

There were a total of 24 responses using the assigned vocabulary in the Memory game. The participants as a group achieved the highest (88\%) level of functional literacy in this game and that may have been caused by the structure of the game, which allowed the participants several opportunities to both view and turn over the matching definition card. This game also had the highest amount (8\%) of any game in the unacquainted category. The Memory game also had the lowest rate of nominal responses $(4 \%)$ and no $(0 \%)$ conceptual responses. This again was related to the design of the game that provided the 'correct' vocabulary and definitions thereby eliminating nominal answers and providing no opportunity to reach the conceptual level. This was a good way to introduce vocabulary but offered little in terms of productive, knowledge building discourse among the participants.

Gameshow was played in week four of the unit and demonstrated varied results. Gameshow is modeled on television quiz shows where participants are given a question and are required to give the correct response within a specified time limit. The students wrote the questions and answers based on their text and class work. In Gameshow participants responded on all levels of scientific literacy where $1 \%$ of the responses were at the unacquainted level, $2 \%$ were at the conceptual level, $43 \%$ were at the nominal level, and the highest amount (54\%) were on the functional level. Gameshow was played several times over weeks 4 and 5 whenever time permitted.

The Pyramid game, which was played twice during the fifth week of the unit, was also derived from a television game show where the contestant is allowed only one clue word per turn that lists a characteristic of the target word. The participants were less familiar with this game format and struggled with the strict rules and confining structure of the game. This game required that the participants use synonyms or defining features (thematic patterns) of the term and they found this difficult. Again, the words used in this game were selected from the assigned list of vocabulary words. There were a total of 38 responses in the Pyramid game spread across categories in similar patterns to those found in Gameshow. There were 3\% unacquainted responses, $44 \%$ nominal responses, $50 \%$ functional responses, and $3 \%$ conceptual responses.

After the completion of one round of Pyramid, there was time for more play and the participants created a variation of the game (called Pyramid 2) where they played a speed round. One student would read the definition and the opponent would be required to name the appropriate vocabulary word. Only one player could answer and if they were incorrect, the question would be passed to the next player. If the participant answered correctly, they received a point and were asked another question. The role of the moderator would be rotated so each participant would have a chance to play.

The total number of responses $(n=38)$ in Pyramid 2 was equal to the Pyramid game. The 
participants achieved a functional level of $63 \%$ in this version of the game, surpassing the level in the first version (50\%). The nominal level (37\%) was slightly less than the original version of the Pyramid game. There were no words that they were unacquainted with and no responses on the conceptual level. This finding suggested that the participants became familiar with the language used repeatedly in these definitions and when supported by this familiar language it became much easier to identify the vocabulary term.

The last game played during the sixth and final week of the unit was Jeopardy. The participants requested to play this game and were well acquainted with the structure and rules of the game. Each student was required to write one question for the game and give it a dollar value (based on the level of difficulty) and the teacher created the remainder of the questions. Adhering to this popular game show format, questions were listed by categories and the responses were to be given in the form of a question.

Jeopardy produced the lowest amount of total responses directly related to the assigned vocabulary $(n=19)$. The functional level of scientific literacy was $63 \%$ and the nominal level was $32 \%$. The level of conceptual responses was $5 \%$, which is the greatest result in this category across all games. There were no $(0 \%)$ responses in the unacquainted category.

\section{Vocabulary Use over Time}

Further, the analysis of the individual games and the levels of scientific literacy attained in each game (Table 2) expanded the understanding of the ways in which instructional games affect the participant's use of scientific vocabulary overtime. For example, during the play of Gameshow where the participants wrote the questions and answers for the game and played several times over the six-week period, the participants demonstrated their gradual understanding of the academic terms. Below is an excerpt of play during the game called Gameshow where it was apparent that they are struggling with the oft-confused terms, weathering and erosion.

Sam: $\quad$ The process of wearing away or to eat away is called?

Hank: Weathering

Concetta: No!

Hank: Erosion.

Sam: $\quad$ Yes, but that doesn't count.

Hank: Why doesn't it count?

Mohammad: You said weathering.

Hank: It's the same thing.

Sam: $\quad$ OK give him a point...those are close.

In this exchange it was clear that the participants were unsure of the definitions and simply allowed Hank to gain the point. Subsequently the question was repeated during a round on another day that week and the participants once again engaged in a conversation discussing the meaning of weathering and erosion. They are clearly still unsure of the differences but they are questioning their understandings. Concetta makes an attempt to use the academic terms learned in the unit but fails to explain the difference between weathering and erosion. The following took place after one participant asked if the terms were the same: 
Ichiro: $\quad$ They're kind of different.

Loretta: Pretty much.

Hank: $\quad$ They both do great damage.

Ichiro: I forgot the difference.

Concetta: $\quad$ Yeah, but they're different things, physically it's like when something really heavy happens like wind and stuff and chemically is like metal...like rusting...

In the fifth week the participants demonstrated a greater understanding of the terms, but more importantly this time they recognized that they were struggling with the definitions and worked together to construct meaning. It is obvious from the exchange that games allowed for a good natured, casual exchange of ideas. Finally, this game offered Hank the opportunity to share his knowledge as he accurately describes this specific type of chemical weathering as oxidation. This response was coded at the conceptual level of scientific literacy because oxidation was not one of the assigned vocabulary words but the concept was discussed in class.

Ichiro: $\quad$ Rusty metal is an example of blank.

Hank: $\quad$ Physical weathering ... no, chemical weathering.

Ichiro: No.

Hank: Chemical weathering.

Ichiro: $\quad$ No it's one word.

Sam: $\quad$ Can you repeat the question?

Ichiro: Rusty metal is an example of?

Loretta: Rusty metal, oh I know this.

Sam: Weathering.

Ichiro: [laughing] Everything is weathering!

Sam: $\quad$ I think I know this ... rock [laughter].

Hank: $\quad$ Could I just say one thing?

Ichiro: Yeah.

Hank: $\quad$ Ox-i-da-tion [slowly sounds out word].

\section{Standard Assessment Compared to Instructional Games}

When comparing the levels of scientific literacy between game response and the final quiz, the participants scored higher on the quiz. However, the final quiz consisted of lower-level closed ended questions that required the participants to respond using the limited functional definitions learned on the vocabulary lists. A typical example of a multiple-choice question on the final quiz was, "A very hard natural igneous rock formed essentially of quartz and orthoclase which is used for monuments and counter tops for kitchens." This question was followed by four choices including the correct response, granite. In contrast, a student generated game question on the same topic read, "Blank is a hard igneous rock used for monuments and buildings." The 
question was restated using the technical (igneous) language within a more common, everyday sentence structure. This example demonstrated that the author of the question both understood the terms and was able to restate the scientific language.

Table 3 Vocabulary Use in Games Compared to the Final Quiz

\begin{tabular}{|l|c|c|c|c|c|}
\hline Level & $\mathrm{N}$ & $\begin{array}{c}\text { Unacquainted } \\
\mathrm{N}(\%)\end{array}$ & $\begin{array}{c}\text { Nominal } \\
\mathrm{N}(\%)\end{array}$ & $\begin{array}{c}\text { Functional } \\
\mathrm{N}(\%)\end{array}$ & $\begin{array}{c}\text { Conceptual } \\
\mathrm{N}(\%)\end{array}$ \\
\hline Use in Games & 207 & $5(2.5)$ & $75(36)$ & $114(55)$ & $13(6.5)$ \\
\hline Final Quiz & 150 & $0(0)$ & $31(21)$ & $119(79)$ & $0(0)$ \\
\hline
\end{tabular}

In games the questions and responses varied, some required higher-level thinking and required participants to use language other than that on the vocabulary list. The structure of games allowed time to talk about the questions and the responses where the final quiz did not. Responses during games allowed the participants to restate the technical definitions using both everyday language and academic language.

\section{Concept Understanding}

Analysis of the transcripts during the play of Pyramid revealed the participants' understandings of scientific concepts and shed light on some of the ways in which they constructed these understandings. The game Pyramid lent itself to this analysis because it required the participants to convey to their partners a list of words that described the characteristics or components of the concept. The participants' word use was restricted according to the game rules and only a one or two-word clue was permitted at each turn. This rule forced the participant to focus on the thematic patterns or main idea of the concept. In the following exchange, Sam gave clues to Mohammad to guess the target word sand.

$\begin{array}{ll}\text { Sam: } & \text { Stone } \\ \text { Mohammad: } & \text { I don't know } \\ \text { Sam: } & \text { Umm ... type of. } \\ \text { Mohammad: } & \text { Type? } \\ \text { Sam: } & \text { Grains } \\ \text { Mohammad: } & \text { Sand }\end{array}$

Examination of Sam's clues and Mohammad's responses provided a window to view their thinking processes. The first clue was stone and Mohammad's reply was understandable. Sam may have been thinking of one of their vocabulary words sandstone. Building on what he has learned about rock types, Sam offered the clue type of also referring to sandstone.

Mohammad questioned this line of thinking, and Sam quickly took another route and offered the word grain. With this appropriate clue that was more closely related to the scientific concept, Mohammad said the correct answer. The words stone, type of, and grains make up the thematic pattern that described sand.

The feedback from Mohammad may have caused Sam to rethink the thematic pattern he was creating for sand. This was a form of peer collaboration because Mohammad's confusion 
about the clues may have prompted Sam to create a clearer pattern of related ideas. They supported one another as they constructed a thematic pattern that meaningfully described the concept.

In addition, the participants demonstrated their conceptual understandings using common, everyday language to explain the concept by substituting language they were more familiar with. Word substitutions were found in the written questions such as ground for earth, seeing for observations, mudslide for landslide, moss for lichen, and drawings for illustrations. The questions that employed these synonyms were coded as functional because during game play they did not interfere with the participants' ability to answer the game questions.

Student constructed questions for Gameshow revealed their conceptual understanding. Some participants restated the concepts in their own words using everyday language indicating that they had sufficient understanding of the concepts to create adequate and appropriate questions. Hank wrote, "Limestone can be broken down by weathering. Answer: Chemical". The students viewed a video in class that explained when carbon dioxide mixed with water, carbonic acid is formed and this acid dissolves calcium carbonate in rocks. The video did not mention limestone specifically, but limestone is one such rock worn down by this process. A classroom discussion about the process followed the viewing of the video and Hank demonstrated his ability to make appropriate associations between the concepts and vocabulary.

\section{Understanding over Time}

Comparison of the pre- and post-assessment showed the knowledge gained overtime.

Table 4 Levels of Scientific Literacy over Time

\begin{tabular}{|l|c|c|c|c|c|}
\hline Level & $\mathrm{N}$ & $\begin{array}{c}\text { Unacquainted } \\
\mathrm{N}(\%)\end{array}$ & $\begin{array}{c}\text { Nominal } \\
\mathrm{N}(\%)\end{array}$ & $\begin{array}{c}\text { Functional } \\
\mathrm{N}(\%)\end{array}$ & $\begin{array}{c}\text { Conceptual } \\
\mathrm{N}(\%)\end{array}$ \\
\hline Pre-assessment & 36 & $19(53)$ & $15(42)$ & $2(5)$ & $0(0)$ \\
\hline Post-assessment & 36 & $5(14)$ & $10(28)$ & $21(58)$ & $0(0)$ \\
\hline
\end{tabular}

Participants demonstrated limited knowledge of the process of erosion in the preassessment. Responses coded as unacquainted such as, "changing of rocks" "when a volcano erupts the lava that comes out" and "erosion is a crack in the earth" appeared on the preassessment. In contrast, participants wrote the following functional level answers to the same question in the post assessment: "The breakdown and wear down of earth" and "The act of slowly destroying something" and "When water, wind, etc., erodes the rock so it will breakdown." These examples show that over time, the participants' increased their knowledge of the concept and demonstrated the ability to connect the concept using both everyday and academic languages. Terms such as breakdown, wear down, and erodes are examples of the usage of scientific language. In addition, the participant alluded to the process of erosion by using the words the act of blending everyday and academic language to describe the concept. These examples demonstrate an emerging understanding of the concept on a continuum of scientific learning.

The examination of game play transcripts provided a window to view the thought processes and growth of the participants as they moved along the continuum of scientific literacy. For example, Hank achieved the functional level of scientific literacy on the pre- 
assessment when he wrote this definition of erosion "the breakdown and wear down of earth." However, Hank reached the conceptual level of scientific exemplified in his response on the post assessment, "When water pulls dirt and rocks into a body of water and the land starts to disappear." In this example, Hank demonstrated conceptual understanding by producing this higher level and more complete description of the process of erosion. Hank also accomplished this primarily by using everyday language to describe the process such as pulls dirt and disappear.

In another example demonstrating how participants were moved along the continuum progressing from one level of scientific literacy to the next, Sam showed that he understood the definition and was capable of using the concept in context to connect the term with the broader scientific theme. For example, Sam's pre-assessment response was coded as unacquainted for his answer to the question "Did the earth always look like it does today?" that read, "No, because of all the new inventions, so life has changed." His functional response on the post-assessment read, "No, because of all the erosion and mass movement."

The responses in the post-assessment revealed an even greater level of functional answers $(67 \%)$ related to mountain building. Participants now included academic terms in their answers such as seismic activity, mass movement, Pangea, and continents. The question "Did the earth always look like it does today? How do you know?" produced these responses: "No, [a] long time ago there was a large continent called Pangea." and "No, because sizmic [sic] activity is always going on." The conceptual level was also achieved in the following example: "No, because the tectonic plates have been moving, rocks have been weathered, mountains have come and gone." In this example both the academic (tectonic plates, weathered) and everyday (come and gone) language were combined to create a complete answer that demonstrated the central idea or concept was understood.

The participants also discussed mountain building in a question that was related to the formation of the Grand Canyon. Some of the functional answers supplied on the post-assessment for this question related to mountain building included the statements: "When two plates moved away from each other, the canyon turned into a ditch" and "From plate rubbing, grinding and overlapping." Similar to the functional responses for erosion, the participants expressed their understandings using both everyday and academic language.

Frequency of use of the concepts was exhibited in these responses. Erosion was not only used to answer the specific question "What is erosion?", it was frequently used appropriately to answer other questions that demonstrated that the participant could connect the vocabulary to other concepts. For example, erosion was cited as a cause of the formation of the Grand Canyon as well as a reason why the earth has changed the way it looks.

\section{Discussion}

Findings suggested that the participants predominantly performed at the functional level during games. Further the participants' vocabulary use and concept understanding during instructional games was comparable to the other measures including assessments and quizzes. That is, the students demonstrated the ability to talk and write adequately and appropriately using scientific language. Significantly, it was only during games that the participants operated at the conceptual level demonstrating an understanding of the relationships among parts and whole of science. If students are to learn to "talk science" as described by Lemke (1990) then they must be given opportunities to use the everyday language they are familiar with it order to gradually build thematic understandings of abstract scientific concepts and the technical language 
associated with the content. The opportunity to use everyday language while discussing science was demonstrated during gameplay where participants discussed the meaning of erosion and weathering. The participants gradually built knowledge over time through socially constructed dialogue. Similar to Hodson's findings, this study found that students must have the opportunity to talk and listen to their peers, "If students are given time to talk, they may 'talk themselves into better understanding"' (1998, p. 157).

Within the context of game play, students had the opportunity to construct meaning through the use of the conversational skills they already possess, providing the means to connect home and school based discourses. The findings in this study were similar to other research that examined classroom discourse (Kamen et al., 1997; Lemke, 1990; Moje et al., 2004) which found that gameplay afforded the opportunity for adolescents to utilize their diverse literacies as well as a means to acknowledge students' diverse ways of knowing and ways of speaking (Gee, 1999a; New London Group, 1996; Street, 1995). Further Gee (1999b) explains the importance of recognizing and utilizing all forms of social language in literacy education because, "It is fruitless, the New Literacy Studies would claim, to concentrate on one of these aspects (language form, activity, identity) without the others" (p.11) .

Lemke (1990) suggested, "Teachers should express all semantic relations among terms and all conceptual relationships for each topic, in ordinary colloquial language as well as in scientific language" (p. 173). Through the process of writing the game questions and answering the questions, students use both registers as they actively participate in the games. Instructional games are well suited to help students bridge this gap through practice translating from everyday to academic science registers. However, this is a slow process and as Solomon (1993) points out, children are reluctant to let go of their socially constructed ideas, which are often influenced by classroom consensus. This is why teacher guidance is critical because "new meanings will need reiteration and social confirmation if they are to thrive" (p. 88).

Ms. Woods reported that her objective was to have her students gain a functional level of knowledge. Research (e.g., Bybee, 1997; Harms \& Yager, 1981; Hurd, 1998) has suggested that traditional science curriculums are geared to teach at the functional level of scientific literacy, which is defined as adequate and appropriate use of scientific language. To reach the goal of achieving scientific literacy for all students, steps must be taken to demystify science by encouraging teachers and students to talk science in common everyday language.

\section{Implications for Practice}

Adolescents are highly adept game players and as educators we can easily integrate their talents into the curriculum using instructional games. As research has suggested (e.g., Hurd, 1998; Kamen, et al, 1997), educators can and should restructure teaching methods to include students' everyday knowledge and language. The inclusion of games as an alternate instructional strategy is inexpensive and simple. In this study Ms. Woods used games well known to her students and since they do not require computer technology, every classroom can afford to create these types of games. These are student-centered activities and practitioners can easily adapt any game format that their students are familiar with involving them in the process of creating the game from beginning to end. Students can negotiate the game selection, create the questions, research the answers, determine the format and rules, and facilitate play accordingly. Students should rotate roles such as emcee or host, scorekeeper, and contestant to avoid boredom and ensure they experience learning from various perspectives. One caveat-Ms. Woods did express concern that it was difficult and time consuming to check all of the questions and 
answers provided by the students but it was a necessary procedure because she found left unchecked, they would share misinformation. As demonstrated in the first erosion and weathering excerpt, when the students were unsure of the correct answers, they were lenient in their decisions and scoring. At times, Ms. Woods supplied some of the questions and answers (as in Jeopardy) to ensure accuracy and full coverage of the topic under investigation.

Ms. Woods suggested variation and it was through trial and error that she discovered which games worked best to provide optimal use to use of language skills. For instance, the Memory game was seen as childlike and dull by many of the players yet she used it initially to familiarize them with the vocabulary. However, upon reflection she realized that her students were simply 'memorizing' definitions and had little true understanding of the meanings. Games such as Pyramid where they were required to use synonyms and conceptually related words proved more demanding and provided a better demonstration of the students' vocabulary and concept understanding. Students were also more engaged in the challenging games and reported that they were more fun.

Engaging disinterested adolescents is a major problem faced by educators in not only science, but all content areas (Alvermann, 2004). Instead of viewing game play as meaningless, this study suggests that educators can and should use the skills students already possess to make content area learning accessible through the addition of a little fun in the curricula. Miss Woods obtained her goal as the students acquired the knowledge of scientific terms and concepts, and the students, much like Sam, were pleasantly surprised to discover that learning can be fun and games. 


\section{References}

Alvermann, D. (2004). Multiliteracies and self-questioning in the service of science learning. In E. Saul (Ed.), Crossing borders in literacy and science instruction: Perspectives on theory and practice (pp. 226-238). Newark, DE: IRA.

Bogdan, R. C. \& Biklen, S. K. (1992). Qualitative research in education: An introduction to theory and methods (2nd ed.). Boston, MA: Allyn and Bacon.

Bybee, R. (1995). Achieving scientific literacy. The Science Teacher, 62(7) 28-33.

Bybee, R. (1997). Achieving scientific literacy. Portsmouth, NH: Heinemann.

Corbin, J., \& Strauss, A. (1990). Grounded theory research: Procedures, canons, and evaluative criteria. Qualitative Sociology, 13 (1), 3-21.

Gee, J. P. (1996). Social linguistics and literacies: Ideology in discourses $\left(2^{\text {nd }}\right.$ ed). Bristol, PA: Falmer Press.

Gee, J.P. (1999a). An introduction to discourse analysis: Theory and method. New York, NY: Routledge.

Gee, J. P. (1999b). Critical issues: Reading and the new literacy studies: Reframing the National Academy of Sciences report on reading. Journal of Literacy Research. Retrieved from: http://findarticles.com/p/articles/mi_qa3785/is_199909/ai_n8857323

Gee, J.P. (2003). What video games have to teach us about learning and literacy. New York: Palgrave.

Harms, H., \& Yager, R. E. (Eds.). (1981). What research says to the science teacher, 3. Washington, DC: National Science Teacher Association.

Henn, M., Weinstein, M., \& Foard, N. (2006). A short introduction to social research. London, UK: Sage Publications Ltd.

Hodson, D. (1998). Teaching and learning science: Towards a personalized approach. Buckingham, UK: Open University.

Hurd, P. (1998). Science literacy: New worlds for a changing world. Science Education, $82,407-418$.

Jacobs, J. W., \& Dempsey, J.V. (1993). Simulation and gaming: Fidelity, feedback, and motivation. In J. V. Dempsey, \& G.C. Sales (Eds.), Interactive instruction and feedback (pp. 197-227). Englewood Hills, NJ: Educational Technology.

Kamen, M., Roth, W.M., Flick, L.B., Shapiro, B., Barden, L., Kean, E. Marble, S., \& Lemke, J. (1997). A multiple perspective analysis of the role of language in inquiry science learning: To build a tower. Electronic Journal of Science Education, 2(1), Retrieved from: http://unr.edu/homepage/jcannon/ejse/kamen_etal.html

King, N. (1986). Play and the culture of childhood. In G. Fein, \& M. Rivkin (Eds.). The young child at play. Washington, DC: National Association for the Education of Young Children.

Lepper, M.R., \& Chabay, R.W. (1985). Intrinsic motivation and instruction: Conflicting views on the role of motivational processes in computer-based education. Educational Psychologist, 20(4), 217-230.

Lemke, J. L. (1990). Talking science: Language, learning, and values. Westport, CT: Ablex.

Malone, T., \& Lepper, M. (1987). Intrinsic motivation and instructional effectiveness in computer-based education. In R. Snow, \& M. Farr (Eds.), Aptitude, learning, and instruction (pp. 255-286). Hillsdale, NJ: Erlbaum. 
Miller, J. D., R. Pardo, \&, F. Niwa. (1997). Public perceptions of science and technology: A Comparative study of the European Union, the United States, Japan, and Canada. Chicago, IL: Chicago Academy of Sciences.

Moje, E.J., Kramer, K., Ciechanowski, K., Ellis, K., Carrillo, R., \& Collazo, T. (2004). Working toward third space in content area literacy: An examination of everyday funds of knowledge and discourse. Reading Research Quarterly, 39(1), 38-70.

Moll, L.C., \& Greenberg, J. (1990). Creating zones of possibilities: Combining social contexts for instruction. In L.C. Moll (Ed.), Vygotsky and education: instructional implications and applications of sociohistorical psychology (pp. 319-348). New York, NY: Cambridge University Press.

Mongillo, G. (2008). Play, games, and attitude: Student and teacher perspectives of educational games. i-Manager's Journal of Educational Technology, 5,(2), 44-54.

National Research Council. (1996). National science education standards. Washington, DC: National Academy Press.

National Science Board. (2002). Science and engineering indicators 2002. Arlington, VA: National Science Foundation.

New London Group. (1996). A pedagogy of multiliteracies: Designing social futures. Harvard Educational Review, 66, 60-92.

Peshkin, A. (1993). The goodness of qualitative research. Educational Researcher, 22(2), 23-29.

Solomon, J. (1993). The social construction of children's scientific knowledge. In P.J Blank \& A.M. Lucas (Eds.), Children's informal ideas in science (pp. 85-101). London, UK: Routledge.

Street, B. V. (1995). Social literacies: Critical approaches to literacy in development, ethnography, and education. New York: Longman.

Yager, R. E. (2000). The history and future of science education reform. Clearing House, 74(1), 51-54. 
Appendix A

Assigned Vocabulary

\section{Investigation 2}

Geology

Geography

canyon

expedition

plateau*

John Wesley Powell

Green River City, WY (Utah)

\section{Investigation 3}

plateau

Lee's Ferry

rock layers

geological illustrations

geologic cross section

river elevation

down river

limestone

sandstone*

shale*

erosion*

\section{Investigation 4}

sedimentary

sand

sandstone

granite

weathering

physical weathering

chemical weathering

erosion

Wentworth scale

mass movement

deposition

*vocabulary word appears on study list in more than one investigation unit 


\section{AUTHOR BIOGRAPHY}

Geraldine Mongillo, Assistant Professor in the Department of Educational Leadership and Professional Studies at William Paterson University is the director of and teaches courses in the Master's of Education-Reading Program. Research interests include multiliteracies, adolescent literacy, and professional development of reading teachers. Recent publications appeared in Contemporary Issues in Technology \& English Language Arts Teacher Education, The Association of Teacher Educators Yearbook, XVI, and i-Manager's Journal of Educational Technology. 